УДК 618.36-02:618.393

DOI

\author{
๑А. В. Бойчук ${ }^{1}$, I. М. Нікітіна ${ }^{2}$, С. А. Сміян ${ }^{2}$, Б. М. Бегош ${ }^{1}$ \\ ${ }_{1}^{1}$ ДВНЗ «Тернопільський державний медичний університет \\ імені І. Я. Горбачевсъкого МОЗ України» \\ ${ }^{2}$ Сумсъкий державний університет

\section{ОСОБЛИВОСТІ ГОРМОНАЛЬНОЇ ФУНКЦІї ФЕТОПЛАЦЕНТАРНОГО КОМПЛЕКСУ ПРИ БАГАТОПЛІДНІЙ ВАГІТНОСТІ}

\begin{abstract}
ОСОБЛИВОСТІ ГОРМОНАЛЬНОЇ ФУНКЦІЇ ФЕТОПЛАЦЕНТАРНОГО КОМПЛЕКСУ ПРИ БАГАТОПЛІДНІЙ ВАГІТНОСТІ. Доведено кореляційний зв'язок між динамікою рівня гормонів фетоплацентарного комплексу та перебігом багатоплідної вагітності. Згідно з проведеними дослідженнями, у вагітних із багатопліддям при концентрації прогестерону до 80 \% від рівня, характерного для одноплідної вагітності, збільшується ризик розвитку передчасних пологів. При несприятливому наслідку вагітності концентрація прогестерону і плацентарного лактогену може відповідати нормі для показників одноплідної вагітності чи перевищувати її на 10 \%, що розцінюється як дисфункція плаценти. Ретельне спостереження за пацієнтками з багатопліддям в антенатальному періоді, профілактика найбільш частих ускладнень вагітності (передчасні пологи, анемія, гестози, затримка розвитку плода), моніторинг з ранніх термінів вагітності дозволяють диференційовано підходити до ведення вагітності і пологів, сприяючи зниженню перинатальної захворюваності і смертності.
\end{abstract}

ОСОБЕННОСТИ ГОРМОНАЛЬНОЙ ФУНКЦИИ ФЕТОПЛАЦЕНТАРНОГО КОМПЛЕКСА ПРИ МНОГОПЛОДНОЙ БЕРЕМЕННОСТИ. Доказана корреляционная связь между динамикой уровня гормонов феетоплацентарного комплекса и течением многоплодной беременности. Согласно проведенным исследованиям, у беременных с многоплодием при концентрации прогестерона до 80 \% от уровня, характерного для одноплодной беременности, увеличивается риск развития преждевременных родов. При неблагоприятном исходе беременности концентрация прогестерона и плацентарного лактогена может соответствовать норме для показателей одноплодной беременности или превышать ее на $10 \%$, что расценивается как диссункция плаценты. Тщательное наблюдение за пациентками с многоплодием в антенатальном периоде, профилактика наиболее частых осложнений беременности (преждевременные роды, анемия, гестоз, задержка развития плода), мониторинг с ранних сроков беременности позволяют дифференцированно подходить к ведению беременности и родов, способствуя снижению перинатальной заболеваемости и смертности.

PECULIANTIES OF HORMONAL FUNCTION OF FETOPLACENTA COMPLEX AT MULTIPLE PREGNANCY. We proved the correlation between changes in the level of hormones of the fetoplacental complex and over multiple pregnancy. According to the conducted studies in multiple pregnancy with progesterone at concentrations up to $80 \%$ from level characteristic of one fetus pregnancy, the risk of development preterm of labor is increased. When adverse pregnancy outcomes concentration of progesterone and placental lactogen can match the rate for indicators single pregnancy or greater than $10 \%$, which is regarded as a dysfunction of the placenta. A thorough follow-up of the female patients with multiple pregnancy in the antenatal period, prevention of the most common complications of multiple pregnancy (premature delivery, anaemia, gestoses, intrauterine foetal growth retardation), monitoring from the early terms of gestation make it possible to carry out a differentiated approach to man- aging pregnancy and delivery, thus helping decrease perinatal morbidity and mortality.

Ключові слова: багатоплідна вагітність, монохоріальна, дихоріальна двійня, гормони фетоплацентарного комплексу.

Ключевые слова: многоплодная беременность, монохориальная, дихориальная двойня, гормоны фретоплацентарного комплекса.

Key words: multiple pregnancy, monochorionic twins, bichorionic twins, fetoplacental hormones.

ВСтУп. Багатоплідна вагітність трапляється в 1,5-2,5 \% спостережень, частіше в сім'ях, де батьки 3 багатоплідної родини, при цьому вирішальну роль має генотип матері $[3,5]$. Особлива увага до багатоплідної вагітності протягом останніх 15-20 років зумовлена значним зростанням числа багатопліддя, що пов'язано з широким застосуванням допоміжних репродуктивних технологій [10]. Поряд з цим багатоплідна вагітність асоціюється із значним числом ускладнень, що супроводжують ії з раннього гестаційного терміну. Саме це і визначає підвищений рівень антенатальних втрат [1, 3, $5,7,9]$. Доведено, що багатоплідна вагітність - як монохоріальна, так і дихоріальна, - $є$ чинником високого ризику перинатальних ускладнень. Найбільш значимими 3 них $€$ невиношування на різних термінах гестації, фретопла- центарна диссрункція, синдром фрето-сретальної гемотрансфузії, дискордантний ріст близнюків, антенатальна загибель плодів, розвиток неврологічних ускладнень у новонароджених.

Перебіг вагітності і пологів при багатоплідді ускладнюють ряд фракторів, найбільш значимими з них є обтяжений соматичний анамнез та вік вагітної, гінекологічні захворювання, гормональні порушення, тип хоріальності. Всі перераховані чинники, як звісно, обтяжують будь-яку вагітність, але при багатоплідді вони мають особливе значення. Таким чином, пацієнтки з багатопліддям складають групу високого ризику щодо розвитку материнських і перинатальних ускладнень. Еволюційно організм вагітної жінки пристосований до виношування одного плода, в зв'язку з цим багатоплідна вагітність спричиняє 
активізацію компенсаторно-пристосувальних механізмів адаптації і насамперед функцій фетоплацентарного комплексу (ФПК) [2].

Найбільш точним і об'єктивним методом оцінки фуннкції плаценти і стану плода $є$ визначення концентрації гормонів фретоплацентарного комплексу в крові вагітної. Зміни цих показників відображають адаптаційний процес під час вагітності, що розвивається, а також свідчать про ступінь захисних реакцій, що активізуються під дією шкідливих фракторів. До числа специфічних маркерів стану ФПК належать плацентарний лактоген, прогестерон, естріол і кортизол. Важливим продуктом комплексу $€$ альфа-сретопротеїн - специфрічний білок плода. Відомо, що під впливом несприятливих материнських і зовнішніх чинників змінюється продукція основних гормонів ФПК, що відображає рівень адаптаційних процесів у системі «мати-плацента-плід» [2, 6, 8].

Мета дослідження - вивчення гормонопродукуючої функції фретоплацентарного комплексу у вагітних з багатопліддям 3 метою раннього виявлення функціональних порушень на різних термінах гестації.

МАТЕРІАЛИ ТА МЕТОДИ. Дослідження проводились на базі Сумського обласного клінічного перинатального центру протягом 2012-2015 років. У процесі наукового дослідження нами проведено обстеження 112 пацієнток із спонтанною багатоплідною вагітністю: 26 вагітних із монохоріальною діамніотичною двійнею, що склали I групу і 86 пацієнток з дихоріальною, діамніотичною двійнею - II група. Контрольну групу склали 30 вагітних із спонтанною одноплідною вагітністю.

Вік жінок у середньому склав $27,8 \pm 3,5$ року (коливався від 18 до 39 років). У віці 30 і більше років було 11 пацієнток I групи (42,3 \%) і 30 жінок II групи (34,8 \%). Відсоток першо- і повторнонароджуючих в обох групах був ідентичним і склав відповідно: у I групі - першонароджуючі $63 \%$, повторнонароджуючі - $37 \%$; у II групі 68 \% - першонароджуючі і 32 \% - повторнонароджуючі.

Окрім клінічного обстеження і загальноприйнятих лабораторних досліджень, здійснювали ультразвуковий моніторинг з ранніх термінів вагітності. Стан фретоплацентарного комплексу оцінювали шляхом вивчення вмісту гормонів імуноферментним методом з використанням стандартних тест-наборів реагентів. Як показники гормонопродукуючої фрункції фретоплацентарного комплексу було вивчено рівень прогестерону, плацентарного лактогену, альфа-фетопротеїну (АФП), естріолу, кортизолу. Дослідження рівня гормонів проводилося з 26-ти тижнів гестації з проміжком у два тижні.

Статистичну обробку отриманого в ході дослідження циоррового матеріалу проводили параметрич- ними методами з використанням комп'ютерних статистичних програм [4]. Статистичні дані цитовані з дисертаційної роботи Ірини Миколаївни Нікітіної «Затримка розвитку плода у вагітних, зайнятих у виробництві суперфоссрату (прогнозування, профрілактика та лікування)», захищеної у 2010 році. В дисертаційній роботі дані обробляли із застосуванням варіаційностатистичного методу аналізу отриманих результатів за допомогаю персонального комп'ютера IBM PC Intel Celeron ${ }^{\mathrm{TM}} 556 \mathrm{MHz}$ та прикладної програми роботи з електронними таблицями Microsoft ${ }^{\circ}$ Excel 97 в середовищі Windows Millenium. Статистичну обробку матеріалу проводили методами варіаційної та парної статистики, а також застосовували метод відмінності з використанням t-критерію Стьюдента. Отримані результати вважали вірогідними, якщо коефріцієнт достовірності р, який знаходили за таблицею Стьюдента, був меншим 0,05.

РЕЗУЛЬТАТИ ДОСЛІДЖЕННЯ ТА ЇХ ОБГОВОРЕННЯ. При дослідженні гормональної фрункції плаценти залежно від хоріальності виявлено такі особливості. У групі вагітних із монохоріальним типом плацентації спостерігається значне зростання прогестерону і плацентарного лактогену відносно норми для одноплідної вагітності (медіана 180, межі 134,25 та 216,25), при цьому спостерігається зниження вмісту кортизолу до 90 \% від норми (табл. 1) [2, 6, 8].

У групі з дихоріальним типом плацентації вміст плацентарного лактогену відповідав середнім показникам контрольної групи, рівень прогестерону, альсрасретопротеїну та кортизолу перевищував показники контрольної групи на 10-30\%. Це зумовлено більш сприятливим перебігом вагітності при дихоріальній двійні та, відповідно, меншою кількістю ускладнень порівняно 3 монохоріальним типом плацентації.

Рівень прогестерону в крові при багатоплідній вагітності на початку III триместру становить 150-160 \% від норми при одноплідній вагітності, подальше зростання рівня цього гормону проходить повільніше і до терміну доношеної вагітності показники між контрольною групою та пацієнтками з багатоплідною вагітністю практично зрівнюються (рис. 1).

Рівень плацентарного лактогену на початку III триместру вагітності перевищує показники контрольної групи на 80-100 \%. В подальшому спостерігається його повільне зростання без різкого підвищення в 28-30 тижнів як при одноплідній вагітності. Починаючи з 30 тижнів вагітності показники при одноплідній та багатоплідній вагітності відрізняються на 20-30 \%. Наприкінці III триместру в контрольній групі спостерігається сповільнення зростання його концентрації (рис. 2).

Концентрація АФП у ІІІ триместрі при одноплідній

Таблиця 1. Рівень гормонів та АФП (\% від норми) залежно від типу хоріальності

\begin{tabular}{|c|c|c|c|c|c|c|}
\hline & \multicolumn{3}{|c|}{ I група $(\mathrm{n}=26)$} & \multicolumn{3}{|c|}{ II група $(n=86)$} \\
\hline & \multirow{2}{*}{ медіана } & \multicolumn{2}{|c|}{ квартилі } & \multirow{2}{*}{ медіана } & \multicolumn{2}{|c|}{ квартилі } \\
\hline & & $q^{1}$ & $q^{2}$ & & $q^{1}$ & $q^{2}$ \\
\hline Прогестерон & $180^{*}$ & 134,25 & 216,25 & 132 & 116 & 149 \\
\hline ПЛ & $160^{*}$ & 111,25 & 196,75 & 100 & 88,5 & 129 \\
\hline АФП & 120 & 80 & 146 & 112 & 93 & 150 \\
\hline Кортизол & $91^{*}$ & 66,5 & 112,5 & 117 & 92 & 140,25 \\
\hline
\end{tabular}

Примітка. * - достовірна різниця $(p<0,05)$ порівняно між I і II групами. 


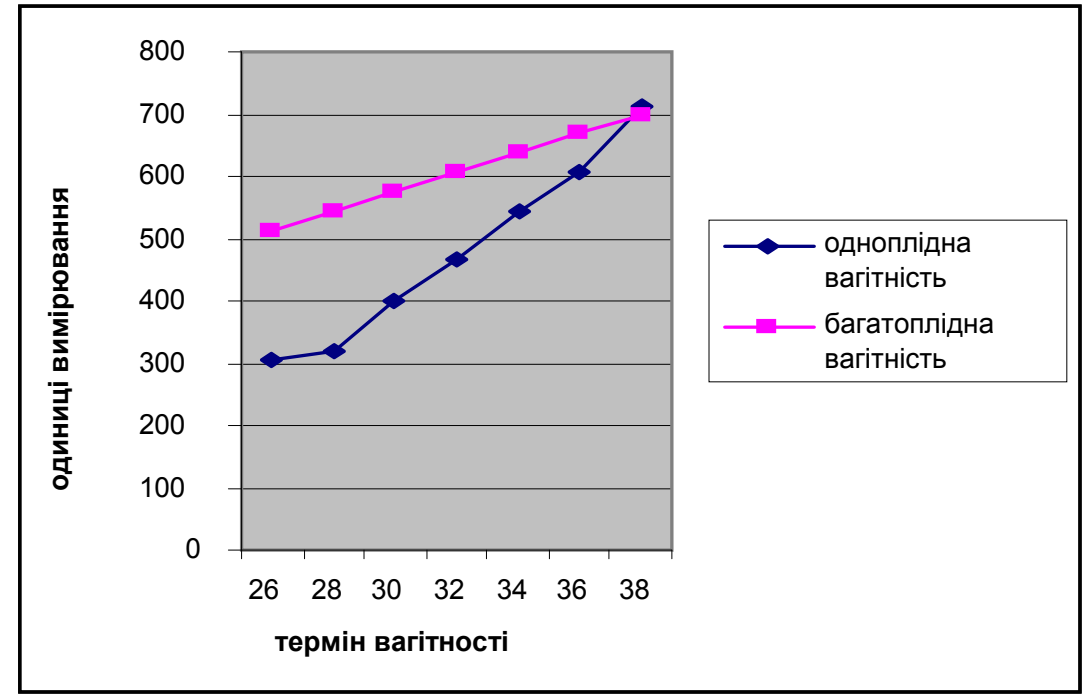

Рис. 1. Рівень прогестерону в крові при одноплідній та багатоплідній вагітності.

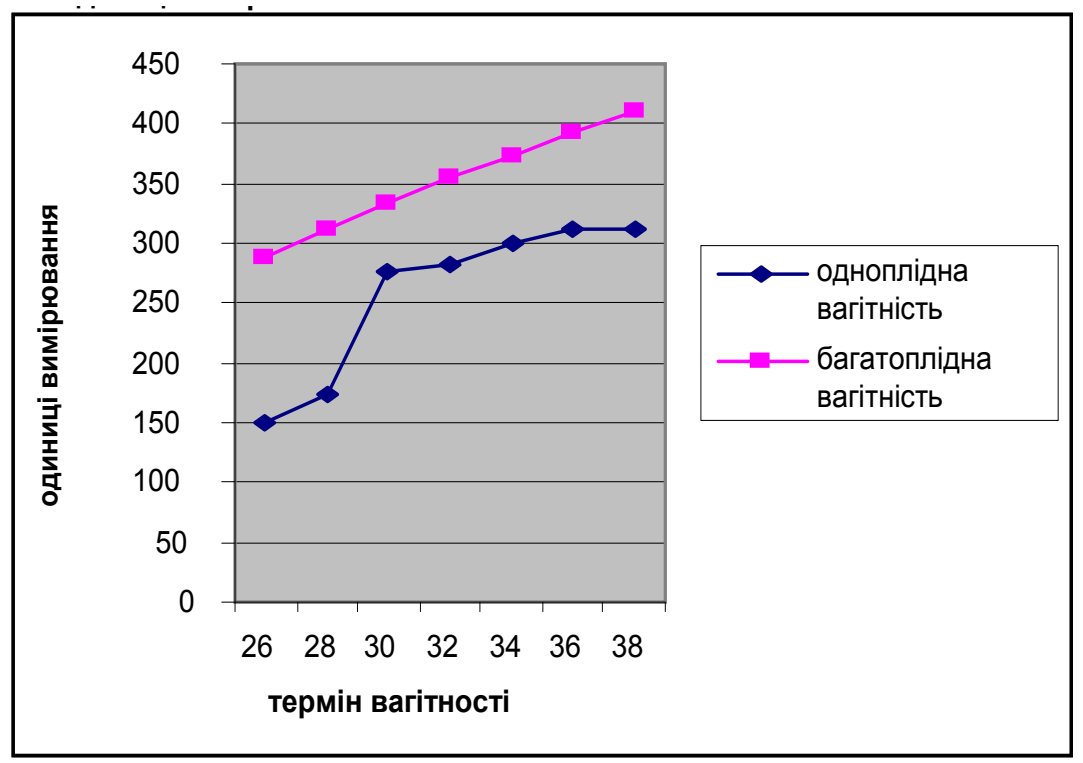

Рис. 2. Рівень пЛ у крові при одноплідній та багатоплідній вагітності.

вагітності має тенденцію до зростання з максимальним рівнем у 30-32 тижні гестації з наступним поступовим зниженням до вихідного рівня. При багатоплідній вагітності на початку III триместру концентрація альфафетопротеїну перевищує норми при одноплідній вагітності на 180-200\%. У подальшому, згідно 3 нашими дослідженнями, відбувається лише зниження концентрації гормону, без піка зростання в 30-32 тижні гестації. Таким чином, у цьому терміні вагітності різниця в концентрації гормону при одноплідній та багатоплідній вагітності складає 20-30 \%, а до 38 тижнів гестації знову досягає 150-180 \% (рис. 3). Така динаміка рівня АФП може бути зумовлена раннім старінням плаценти з порушенням іiї функції, а також ростом і дозріванням плодів при багатоплідді.

Концентрація естріолу при одноплідній вагітності має чітку тенденцію до зростання протягом всього III триме- стру. За нашими даними, при багатоплідній вагітності вихідний рівень естріолу на початку III триместру знижений на 50 \% від показників контрольної групи, в подальшому спостерігається незначний приріст, збільшуючись до 38 тижнів на 10-15\% від вихідного рівня (рис. 4). Оскільки до 90 \% естріолу наприкінці III триместру продукується плодом, то відповідні зміни при багатоплідній вагітності, імовірно, пов'язані з затримкою росту плодів на тлі фетоплацентарної диссрункції.

Рівень кортизолу при багатоплідді також знижений на 30-50 \% порівняно з показниками при одноплідній вагітності (рис. 5), що пов'язано з посиленою стресорною реакцією організму при багатоплідній вагітності.

Як видно з поданих даних, вміст у крові АФП, прогестерону і плацентарного лактогену в пацієнток з багатоплідною вагітністю складає 100-130 \% від концентрації при одноплідній вагітності, при цьому вміст естріолу та 


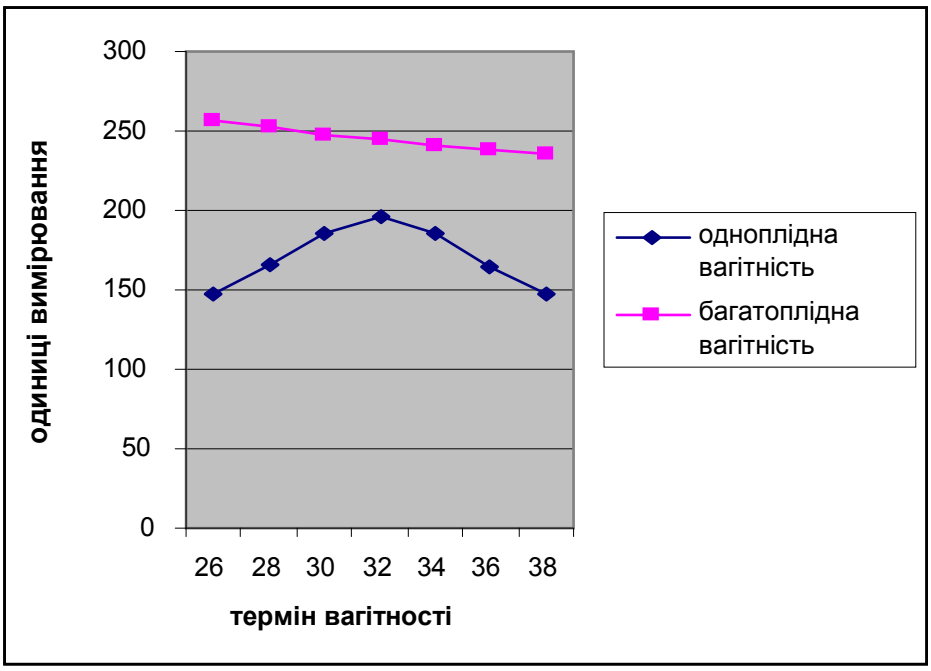

Рис. 3. Рівень АФП у крові при одноплідній та багатоплідній вагітності.

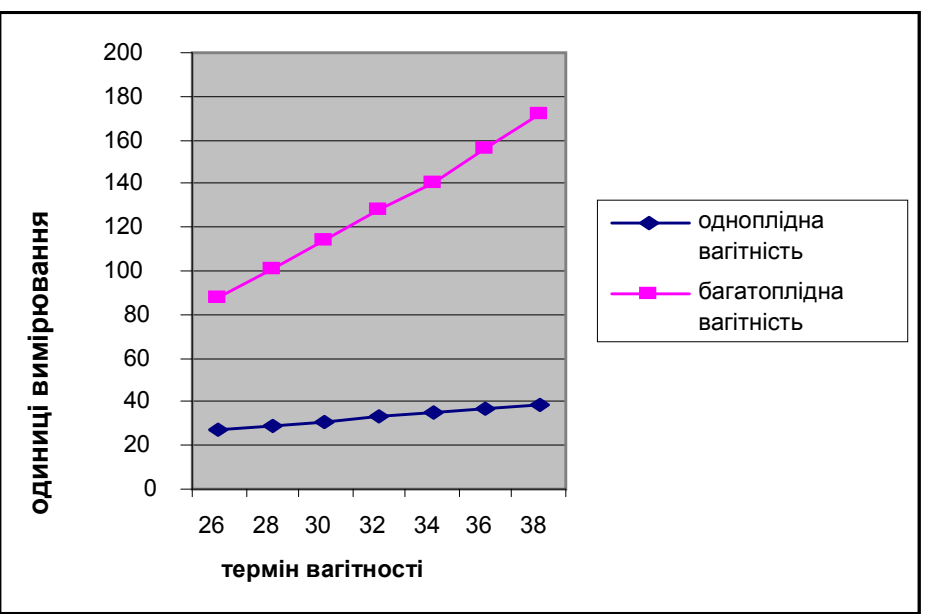

Рис. 4. Рівень естріолу в крові при одноплідній та багатоплідній вагітності.

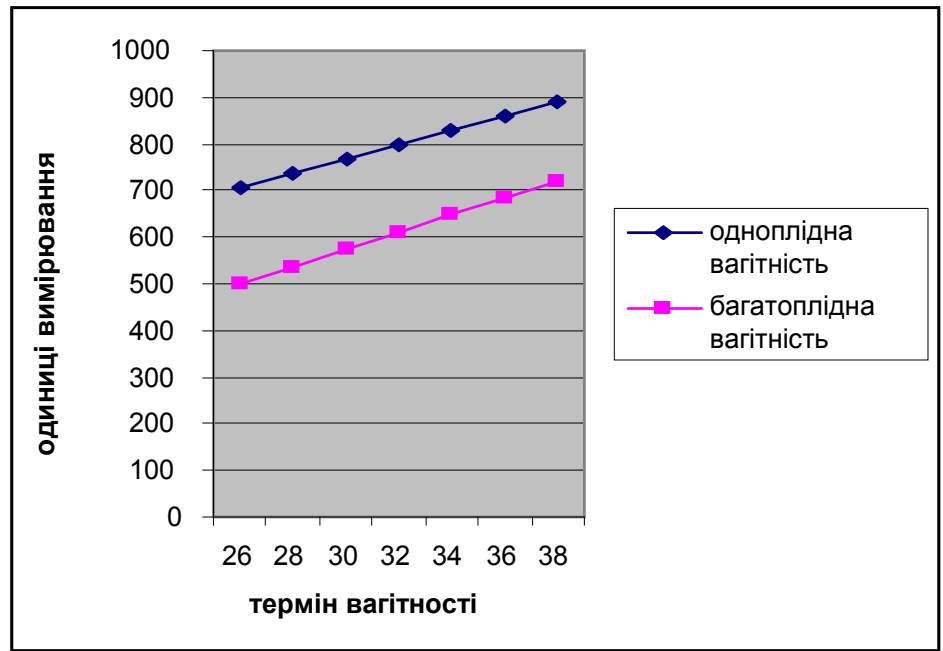

Рис. 5. Рівень кортизолу в крові при одноплідній та багатоплідній вагітності. 
кортизолу знижений на 20-30\%.

Аналіз гормональної фрункції залежно від термінів розродження виявив, що у групі з передчасними пологами відмічено різке зниження рівня кортизолу (медіана 87, квартилі 53 і 127) і зростання рівня прогестерону (медіана 183, квартилі 119,5 і 202) (табл. 2).

Аналізуючи перинатальні наслідки та їх зв'язок 3 вмістом гормонів ФПК, виявлено, що у пацієнток, діти яких були переведені на подальше етапне виходжування та лікування у відділення патології новонароджених, спостерігалось зниження рівня прогестерону, плацентарного лактогену та кортизолу, порівняно 3 пацієнтками, діти яких виписані додому в задовільному стані (табл. 3).

При аналізі зв'язку маси тіла новонароджених та гормональної фрункції плаценти виявлено значне зниження кортизолу в крові вагітних, у яких народилися діти масою менше 2500 г (медіана 50,5, квартилі 47 і 99), у пацієнток $з$ масою новонароджених більше 2500 г відмічено підвищення рівня прогестерону на 40 \% порівняно 3 контрольною групою. При дисоційованому розвитку плодів на $25 \%$ підвищується концентрація прогестерону і на 21 \% АФП. У концентраціях

Таблиця 2. Рівень гормонів (\% від норми) залежно від термінів розродження

\begin{tabular}{|c|c|c|c|c|c|c|}
\hline & \multicolumn{3}{|c|}{$\begin{array}{c}\text { I група - передчасні пологи } \\
(\mathrm{n}=26)\end{array}$} & \multicolumn{3}{|c|}{$\begin{array}{c}\text { II група - термінові пологи } \\
(\mathrm{n}=86)\end{array}$} \\
\hline & \multirow{2}{*}{ медіана } & \multicolumn{2}{|c|}{ квартилі } & \multirow{2}{*}{ медіана } & \multicolumn{2}{|c|}{ квартилі } \\
\hline & & $q^{1}$ & $q^{2}$ & & $q^{1}$ & $q^{2}$ \\
\hline Прогестерон & $183^{*}$ & 119,5 & 202 & 137 & 120 & 176,5 \\
\hline ПЛ & $108^{*}$ & 88,5 & 176,5 & 107 & 91 & 151,75 \\
\hline АФП & 127 & 84,75 & 144,5 & 113 & 91 & 148,5 \\
\hline Кортизол & $87^{*}$ & 53 & 127 & 112 & 91 & 135 \\
\hline
\end{tabular}

Примітка. * - достовірна різниця (р<0,05) порівняно між групами з передчасними та терміновими пологами.

Таблиця 3. Рівень гормонів (\% від норми) і перинатальні наслідки

\begin{tabular}{|c|c|c|c|c|c|c|}
\hline & \multicolumn{3}{|c|}{ בіти, переведені на етапне виходжування (n=42) } & \multicolumn{3}{|c|}{ Діти, виписані додому (n=70) } \\
\hline & \multirow{2}{*}{ медіана } & \multicolumn{2}{|c|}{ квартилі } & \multirow{2}{*}{ медіана } & \multicolumn{2}{|c|}{ квартилі } \\
\hline & & $q^{1}$ & $q^{2}$ & & $q^{1}$ & $q^{2}$ \\
\hline Прогестерон & $112^{*}$ & 93 & 156 & 137 & 107 & 168 \\
\hline ПЛ & $109 *$ & 91 & 147 & 122 & 96 & 148 \\
\hline АФП & 119 & 88 & 146 & 116 & 93 & 144 \\
\hline Кортизол & $94^{*}$ & 71 & 123 & 113 & 95 & 137 \\
\hline
\end{tabular}

Примітка. * - достовірна різниця $(p<0,05)$ порівняно між групами.

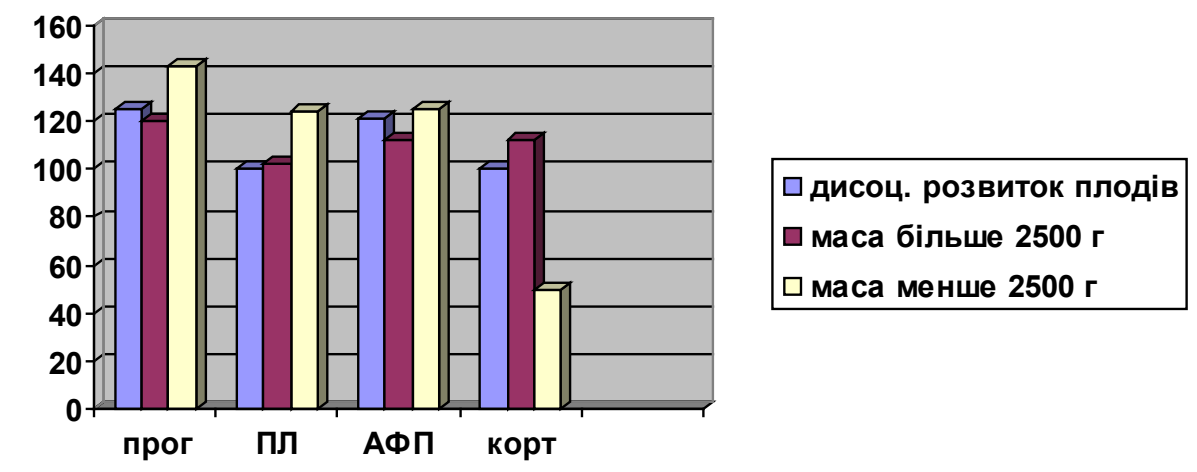

Рис. 6. Вміст гормонів та маса тіла при народженні.

інших гормонів достовірної різниці не виявлено (рис. 6).

ВисновкИ. 1. Концентрація прогестерону, плацентарного лактогену та альфра-фретопротеїну при багатоплідній вагітності збільшується на 30-50 \% від норми.

2. Згідно з проведеними дослідженнями, у вагітних із багатопліддям при концентрації прогестерону до 80 \% від рівня, характерного для одноплідної вагітності, збільшується ризик розвитку передчасних пологів.

3. При несприятливому наслідку вагітності концентрація прогестерону і плацентарного лактогену може 
відповідати нормі для показників одноплідної вагітності чи перевищувати її на $10 \%$, що розцінюється як дисфрункція плаценти.

4. Кореляції між рівнями інших гормонів (кортизолу, естріолу) і перинатальними наслідками не виявлено.

5. Ретельне спостереження за пацієнтками з багатопліддям в антенатальному періоді, профрілактика найбільш частих ускладнень вагітності, моніторинг з ранніх термінів вагітності дозволяють диференційовано підходити до ведення вагітності і пологів, сприяючи зниженню перинатальної захворюваності і смертності.

ПЕРСПЕКТИВИ ПОДАЛЬШИХ ДОСЛІДЖЕНЬ ПОЛЯгають у поглибленні вивчення проблем антенатального догляду при багатоплідній вагітності. Отримані дані дозволяють стверджувати, що рівень гормонопродукуючої срункції фретоплацентарного комплексу при багатоплідній вагітності може слугувати діагностичним критерієм для об'єктивної оцінки стану вагітної і плодів, а також прогнозувати розвиток можливих ускладнень під час вагітності,

в пологах та перинатальних ускладнень. СПИСОК ЛІТЕРАТУРИ

1. Багатоплідна вагітність : навч. посіб. / за ред. Вдовиченко Ю. П. - К., 2011. - 360 с.

2. Егорова А. Т. Фетоплацентарная недостаточность: клинические и морорологические аспекты : методические рекомендации / А. Т. Егорова, М. И. Базина, А. К. Кириченко. - Красноярск, 2002. - 43 с.

3. Современные проблемы многоплодной беременности / В. И. Краснопольский, С. В. Новикова, М.В.Капустина [и др.] // Российский вестник акушера-гинеколога. - 2009. № 2. - С. 79-81.

4. Лапач С. Н. Статистические методы в медикобиологических исследованиях с использованием Exel / С. Н. Лапач, А. В. Чубенко, П. Н. Бабич. - К. : Морион, 2000. $-320 \mathrm{c}$.

5. Гипотрофия плода при многоплодной беременности: антропометрические и гемодинамические критерии ранней

антенатальной диагностики / В. С. Прохорова, Н. Г. Павлова, В. В. Козлов, А. В. Новикова // Журнал акушерства и женских болезней. - 2001. - № 2. - С. 50-54.

6. Сичинава Л. Г. Монохориальная двойня: особенности течения беременности и родов, перинатальные исходы I Л. Г. Сичинава, С. А. Калашников, О. Б. Панина // Акушерство и гинекология. - 2003. - № 2. - С. 8-12.

7. Многоплодие: диагностика и тактика ведения беременности и родов / Л. Г. Сичинава, О. Б. Панина, С. А. Калашников [и др.] // Вопросы гинекологии, акушерства и перинатологии. - 2002. - № 1. - С. 47-51.

8. Фролова О. Г. Многоплодные роды и их исходы для матери / О. Г. Фролова, М. Е. Матвеенко // Проблемы беременности. - 2001. - № 3. - С. 3-5.

9. Blickstein I. Multiple Pregnancy. Epidemiology, Gestation \& Perinatal outcome / I. Blickstein, L. G. Keith. - 2005, Informa UK Ltd. -946 p.

10. The risk of birth defects in dichorionic twins conceived by assisted reproductive technology / T. Kuwata, S. Matusubara, A. Ohkuchi [et al.] // Twin Res. - 2004. - Vol. 7. - P. 223-227.

Отримано 10.02.16 